\title{
抗腫瘍活性を中心とした新規生物活性天然物の探索研究
}

\author{
横須賀章人
}

\section{Discovery of Novel Biologically Active Compounds of Natural Origin, with a Focus on Anti-tumor Activity}

\author{
Akihito Yokosuka \\ Department of Medicinal Pharmacognosy, School of Pharmacy, Tokyo University of Pharmacy and \\ Life Sciences; 1432-1 Horinouchi, Hachioji, Tokyo 192-0392, Japan.
}

(Received May 28, 2015)

\begin{abstract}
Numerous clinically valuable medicines, including anticancer drugs, have been developed from biologically active natural compounds and their structurally related derivatives. This review discusses novel natural compounds with promising biological activities and those with novel chemical structures. Glaziovianin A, an isoflavone isolated from the leaves of Ateleia glazioviana (Legminosae), inhibited cell cycle progression at the M-phase with an abnormal spindle structure. AU-1 and YG-1, $5 \beta$-steroidal glycosides isolated from the whole plants of Agave utahensis and the underground parts of Yucca glauca (Agavaceae), induced apoptosis of HL-60 cells via caspase-3 activation. Lycolicidinol, an alkaloid isolated from the bulbs of Lycoris albiflora (Amaryllidaceae), induced transient autophagy and morphological changes in mitochondria in the early stage of the apoptotic cell death process in HSC-2 cells. Taccasterosides isolated from the rhizomes of Tacca chantrieri (Taccaceae) and stryphnosides isolated from the pericarps of Stryphnodendron fissuratum (Legminosae) are steroidal and triterpene glycosides with unique chemical structures having novel sugar sequences.
\end{abstract}

Key words_-natural product; anti-tumor activity; apoptosis; isoflavone; alkaloid; glycoside

\section{1. はじめに}

天然由来の生物活性化合物あるいはそれらの基本 骨格を基にアナログ合成された化合物から，新規医 薬品が開発された例は多い。特に抗がん剂において は，米国食品医薬品局（Food and Drug Administration; FDA）で 1981 年から 2010 年に承認された 医薬品のうち約 $40 \%$ が天然由来の化合物とそれら

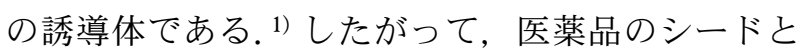
なり得る新規生物活性天然物を探索することは現在 でもなお意義ある研究課題と考えられる，筆者は， 伝承生薬の基原植物を含めた高等植物から, ヒト腫 瘍細胞に対して新規作用メカニズムにより選択的な 細胞毒性を示す化合物の探索を中心に研究を展開し てきた。本稿では，筆者の代表的な研究成果につい て紹介する.

東京薬科大学薬学部漢方資源応用学教室（T192-0392 東京都八王子市堀之内 1432-1)

e-mail: yokosuka@toyaku.ac.jp

本総説は, 平成 26 年度日本薬学会関東支部奨励賞の受 賞を記念して記述したものである.

\section{2. 微小管ダイナミクスに作用する新規抗腫瘍活} 性イソフラボン

ブラジル原産のマメ科 Ateleia glazioviana の葉の エタノール抽出エキスが HL-60 ヒト白血病細胞に 対して顕著な細胞毒性を示したことから，活性成分 の分離・精製を行った. その結果, 1 種の新規化合 物を含む 4 種のイソフラボン（AG-1-AG-4）を単 離した。化合物 AG-1-AG-4 はいずれも HL-60 細 胞に対して細胞毒性を示した $\left(\mathrm{IC}_{50} 0.29-23 \mu \mathrm{M}\right)$. それらのうち， HL-60 細胞に対して最も強い細胞 毒性（ $\mathrm{IC}_{50} 0.29 \mu \mathrm{M} ）$ を示した新規イソフラホン AG-1 glaziovianin A と命名した（Fig. 1).

Glaziovianin A について (財) 癌研究会・ヒトがん 細胞パネルスクリーニングを行つた結果，有効濃度 が十分に低く，腫瘍細胞に対する感受性の差が認め られた. 2)さらに，COMPARE 解析により，薬剤感 受性パターン（フィンガープリント）を既存の抗が ん剂や抗腫瘍活性物質と比較した。その結果, glaziovianin A は微小管重合阻害物質に類似した活 性スペクトルを示したことから，作用点を微小管と 


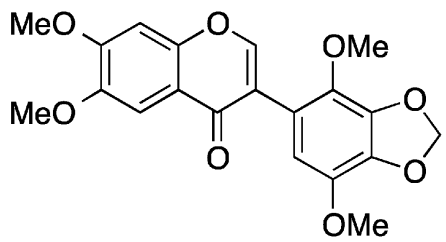

Fig. 1. Structure of Glaziovianin A (AG-1)

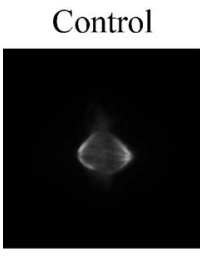

(A)

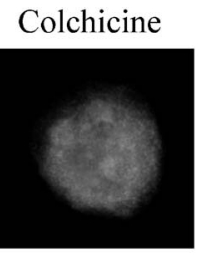

(B)

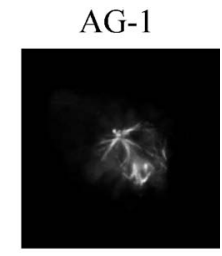

(C)
Fig. 2. Effects of Colchicine and AG-1 on Tubulin Cytoskeletons in 3Y1 Cells

$3 \mathrm{Y} 1$ cells were treated with $1 \mu \mathrm{M}$ of colchicine (B) and $3 \mu \mathrm{M}$ of AG-1 (C) for $18 \mathrm{~h}$. Tubulin cytoskeletons stained with anti- $\alpha$-tubulin antibodies.

予想した。 そこで，本化合物の作用メカニズムの解 明のため，3Y1 ラット線維芽細胞を用いて，細胞周 期及び微小管への影響を検討した。細胞分裂期の形 態観察において，微小管阻害剂である colchicine は 微小管を破壊し, 紡錘体の形成を阻害したのに対し, glaziovianin A は微小管ダイナミクス（微小管の伸 長と短縮）を阻害し，多極紡錘体が形成された。し たがって, glaziovianin A は, colchicine とは異なる 作用機序で細胞周期を分裂期（M 期）で停止させ ていることが示された (Fig. 2). ${ }^{3)}$

現在臨床応用されている抗がん剂のうち, 微小管 作用薬としては微小管の重合を阻害するビンカアル カロイド類や，微小管の重合を過度に促進するタキ サン類が知られている。 いずれの化合物も微小管の 広範囲に結合し，微小管ネットワークの破壊をもた らす。その一方, 2010 年に海洋天然物 halichondrin B から開発された eribulin は, 微小管ネット ワークを破壞せずに微小管の伸長のみを阻害する微 小管ダイナミクス阻害薬である. Eribulin は既存の 微小管作用薬とは微小管への結合部位が異なるた め, 化学療法の治療歴があり, 微小管作用薬に耐性 が発現したがん患者に対しても低用量で奏功する.

Glaziovianin A は含窒素化合物でないにもかかわ らず，微小管に作用を示す点で興味深い。さらに, 微小管ネットワークにはほとんど影響を与えずに, 分裂期に多極紡錘体構造を誘導して細胞周期を停止

させることから, eribulin とは作用メカニズムの異 なった，微小管ダイナミクスを作用点とする新しい 抗腫瘍活性物質と言える。 その後, glaziovianin A の全合成の達成, ${ }^{4)}$ 類縁化合物の創製と構造活性相 関が明らかとなつた. ${ }^{5,6)}$ 最近では，本化合物が細胞 のがん化により活性化した上皮増殖因子受容体 (epidermal growth factor receptor; EGFR) のエンド ソームによる輸送・成熟化を阻害し，アポトーシス を誘導することが明らになっている. ${ }^{7)}$

\section{3. アポトーシス誘導活性を示すステロイド配糖} 体

筆者は，ユリ科やリュウゼツラン科などの主に観 賞用として用いられる植物から腫瘍細胞毒性物質の 探索を行い，これまでに数多くのステロイド配糖体 を単離・構造決定し，それらの腫瘍細胞毒性を評価 してきた. ${ }^{8-13)}$ その過程において, リュウゼッラン 科 Agave utahensis の全草より HL-60 細胞に対して アポトーシスを誘導する $5 \beta$-スピロスタノール配糖 体（AU-1）を見い出した（Fig. 3)。一般的に，又 テロイド配糖体による細胞死は，化合物の持つ非特 異的な膜破壊によるネクローシスとされていた。し かし，AU-1 は HL-60 細胞に対して caspase-3 を活 性化し，アポトーシス型の細胞死（核クロマチンの 凝縮と DNA の断片化）を誘導することを明らかに

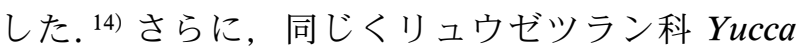
glauca の地下部から，HL-60 細胞に対して細胞毒 性を示す $5 \beta$-スピロスタノール配糖体（YG-1）と $5 \beta$-フロスタノール配糖体（YG-16）を単離した (Fig. 4)。これらの化合物は，ステロイド骨格の F 環部分の構造のみが異なるが，同程度の細胞毒性

(YG-1: IC $_{50} 2.5 \mu \mathrm{M}$; YG-16: IC $_{50} 4.4 \mu \mathrm{M}$ ) を示し, 核クロマチンの凝縮が確認された。さらに，YG-1 と YG-16 の細胞生存率と caspase-3 の活性化を経時 的に確認した結果，YG-1 は 6 時間で caspase-3 の 活性化を伴った細胞死が確認された。一方，YG-16 は 16 時間で caspase-3 の上昇が確認され，それに

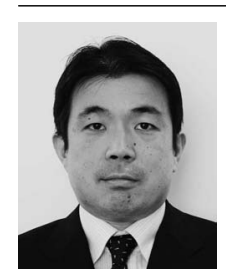

横須賀章人
東京薬科大学薬学部講師。1997 年東京 薬科大学薬学部卒業, 1999 年同修士課 程修了後, 同助手に着任, 2004 年博士 (薬学) 取得, 2007 年同助教, 2011 年 より現職. 専門は, 生薬学・天然物化 学. 


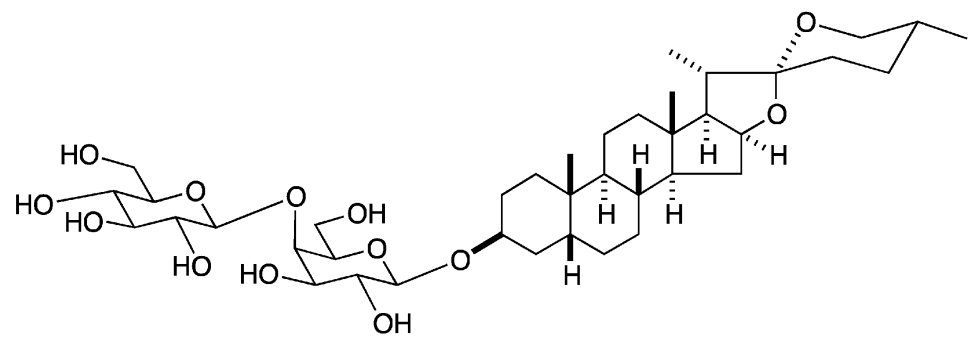

Fig. 3. Structure of AU-1

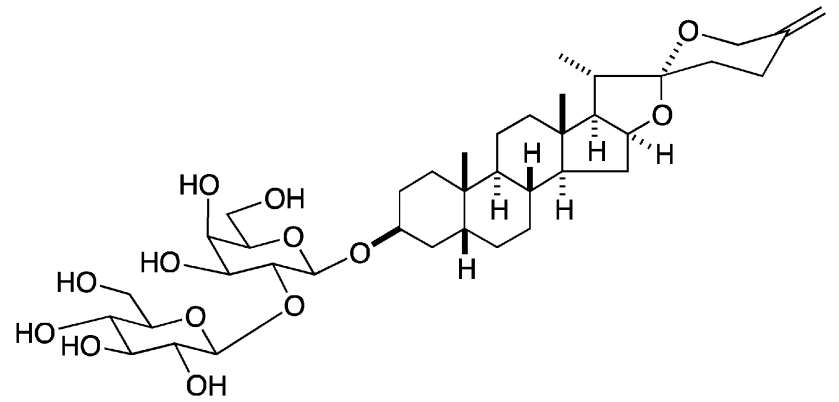

YG-1

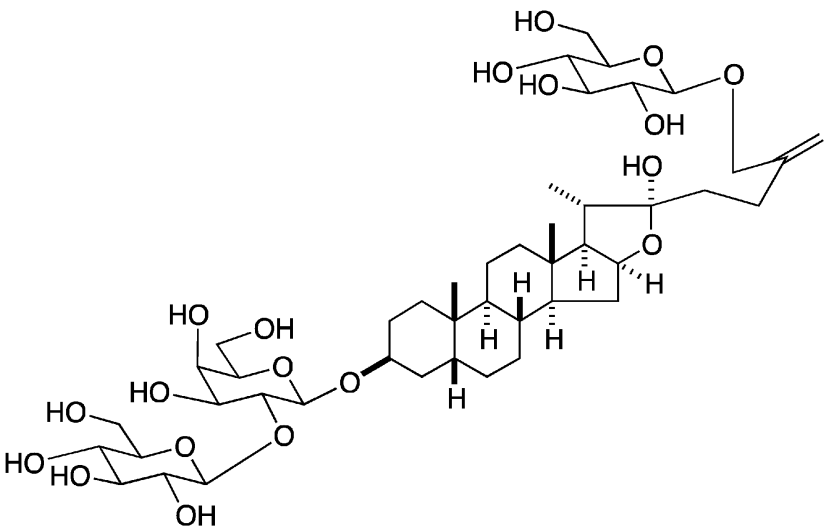

YG-16

Fig. 4. Structures of YG-1 and YG-16

伴つて細胞生存数が減少した（Figs. 5 and 6). し たがって，F 環の開裂の有無によりアポトーシス誘 導のメカニズムになんらかの違いがあることが示唆 された. ${ }^{15)}$ 現在さらに，一連のステロイド配糖体類 の構造活性相関と作用メカニズムの検討を行ってお り，ステロイド配糖体の新規アポトーシス誘導剤と しての展開が期待される.

4. オートファジーを伴った細胞死を誘導するア ルカロイド

多くの抗がん剂は腫瘍細胞に対してアポトーシス 型の細胞死を誘導することから，抗がん剤の開発に おいてアポトーシスの誘導活性が重要視されてき た.一方で，アポトーシスとは異なる形態の細胞死 があることが数多く報告されており，その1つに オートファジーがある. オートファジーとは自己の 細胞内のタンパク質をリソソームが分解し生きのび る現象（自食現象）である.がん細胞においては, がん組織が拡大・増殖する際に栄養血管の発達が追 いつかず，低酸素・低栄養状態となり一時的にオー トファジーが観察されるといった報告や，がん細胞

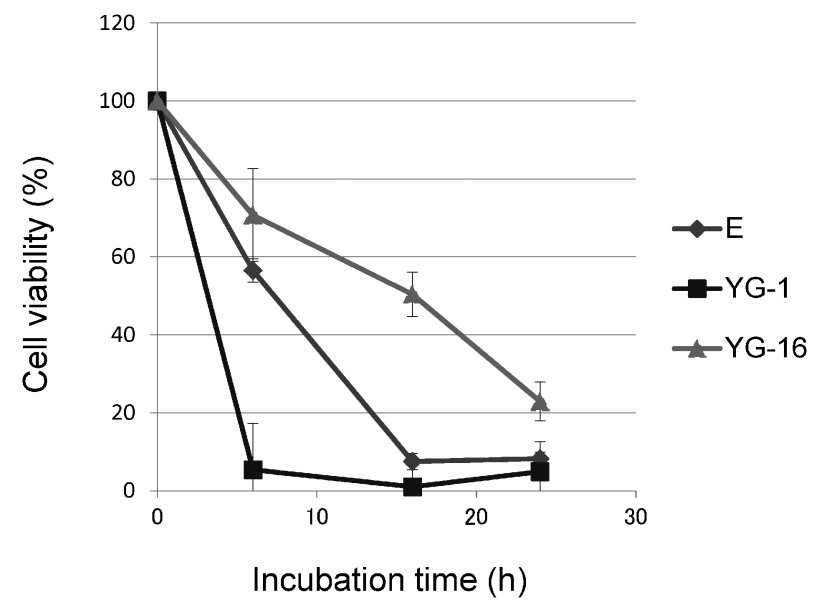

Fig. 5. Cell Viability of HL-60 Cells Treated with YG-1, YG-16, or Etoposide (E)

Cell viability was determined by an MTT assay after incubation with 20 $\mu \mathrm{g} / \mathrm{mL}$ of YG-1 or YG-16, or $10 \mu \mathrm{g} / \mathrm{mL}$ of etoposide (E) at 6, 16, and $24 \mathrm{~h}$. Data represent the mean \pm S.E.M. of three experiments.

に直接的にオートファジー型の細胞死を誘導するい くつかの化合物の報告がある. しかしながら，オー トファジーの誘導を作用機序とする抗がん剤は現在 までに開発されていないことから，オートファジー 


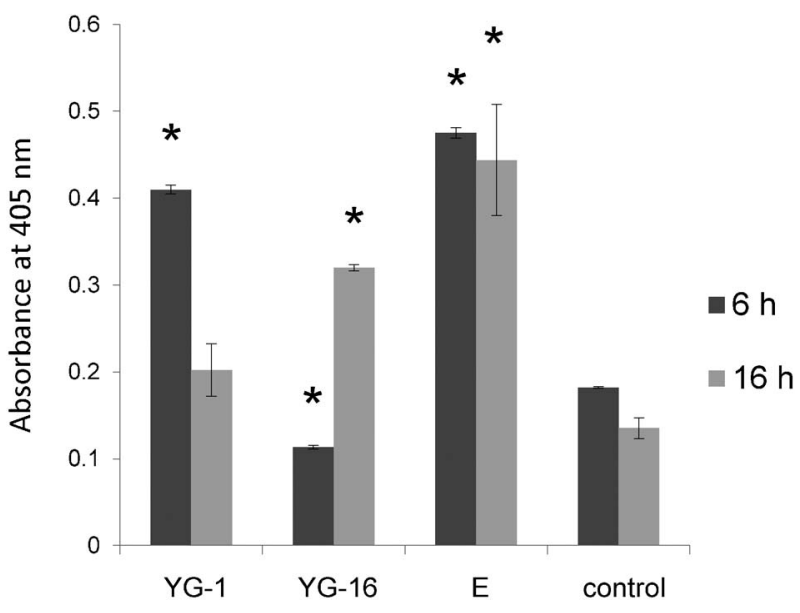

Fig. 6. Caspase-3 Activity in the YG-1, YG-16, or Etoposidetreated HL-60 Cell Lysates

$\mathrm{HL}-60$ cells were incubated at $37^{\circ} \mathrm{C}$ for $6 \mathrm{~h}$ or $16 \mathrm{~h}$ with $20 \mu \mathrm{g} / \mathrm{mL}$ of YG-1, YG-16, or $10 \mu \mathrm{g} / \mathrm{mL}$ of etoposide (E). Data represent the mean \pm S.E.M. of three experiments. Results with $p<0.05$ were considered significantly different from the control group, and are marked with asterisk.<smiles>O=C1N[C@]2(C=C[C@@H](O)[C@@H](O)[C@H]2O)C2=Cc3c(c(O)c4c(c32)OCO4)O1</smiles>

Fig. 7. Structure of Lycoricidinol

の誘導を作用点とする天然物の探索を行つた.

ヒガンバナ科 Lycoris albiflora の鱗茎のメタノー ル抽出エキスから 22 種の化合物を単離した。これ らのうち，フェナンスリジン型アルカロイドである lycoricidinol は，HL-60 細胞及び HSC-2 ヒト口腔 扁平上皮がん細胞に対し強い細胞毒性 $\left[\mathrm{IC}_{50} \quad 0.018\right.$ $\mu \mathrm{M}$ (HL-60), $0.05 \mu \mathrm{M}$ (HSC-2)] を示した (Fig. 7).

HSC-2 細胞に対しては, 24 時間の処理でアポトー シス型の細胞死を誘導することが明らかとなった。 また，培養の初期段階（3 時間接触時）にオート ファゴソーム結合タンパク質である LC3 の集積, ミトコンドリアの萎縮と黒変化が観察され, さら に，オートファジー阻害剤である 3-methyladenine との併用により細胞毒性が減弱した. このことから, lycoricidinol は，HSC-2 細胞に対して一過性のオー トファジー発現を経てアポトーシスを誘導し，この 一過性のオートファジーの誘導が強力な細胞毒性に 寄与していることが示唆された. ${ }^{16)}$
5. 複雑な糖鎖構造を有するステロイド及びトリ テルペン配糖体

高等植物からの新規生物活性天然物を探索する過 程で，構造的に興味深い化合物が単離されている. タシロイモ科 Tacca chantrieri は，中国ではその根 茎を「蒟蒻薯」と称し, 民間的に胃潰瘍, 腸炎, 肝 炎などの治療に用いられている．T. chantrieri の根 茎のメタノール抽出エキスより，ジアリルヘプタノ イド，ジアリルヘプタノイド配糖体，エルゴスタン 配糖体，スピロスタン配糖体，フロスタン配糖体， プソイドフロスタン配糖体，コレスタン配糖体， ウィザノライド配糖体など，新規化合物 39 種を含 む計 41 種（TC-1-TC-41）の化合物を単離し，それ らの化学構造を明らかにした. ${ }^{17-24)}$ 単離された化合 物のうち，いくつかのジアリルヘプタノイド並びに それらの配糖体，スピロスタン配糖体に HL-60 細 胞に対する細胞毒性活性が認められ，構造活性相関 に関する知見が得られた。新規エルゴスタン配糖体 （TC-18）は D-glucose のみからなる従来にない複雑 な糖鎖構造を有しており，その構造を各種二次元 NMR $\quad\left[{ }^{1} \mathrm{H}-{ }^{1} \mathrm{H} \quad\right.$ shift correlation spectroscopy (COSY), ${ }^{1} \mathrm{H}$-detected heteronuclear multiple-quantum coherence (HMQC), ${ }^{1} \mathrm{H}$-detected heteronuclear multiple-bond connectivity (HMBC), nuclear Overhauser effect spectroscopy (NOESY), ${ }^{1} \mathrm{H}$-detected heteronuclear single-quantum coherence (HSQC)totally correlated spectroscopy (TOCSY), the onedimensional (1D)-selective-TOCSY 等］を含むスぺ クトルの解析と化学変換により決定した（Fig. 8).

マメ科 Stryphnodendron fissuratum は，ブラジル で民間的にその樹皮や葉を止血，止瀉薬として用い られている. S. fissuratum の果皮のエ夕ノール抽出 エキスより 13 種の新規トリテルペン配糖体（SF-1SF-13）を単離し，それらの化学構造を，二次元 NMR を中心としたスペクトル解析により明らかに した。 その結果，一部の新規化合物（SF-3-SF-6） において末端 L-arabinosyl 基が通常の ${ }^{4} \mathrm{C}_{1}$ 型配座で はなく, ${ }^{1} \mathrm{C}_{4}$ 型配座として存在していることを, ${ }^{1} \mathrm{H}-,{ }^{13} \mathrm{C}-\mathrm{NMR}$ の化学シフト值, ${ }^{1} \mathrm{H}-\mathrm{NMR}$ のスピン 結合定数 $\left(J\right.$ 值)，アノマーの ${ }^{1} J_{\mathrm{C}-\mathrm{H}}$ 值, HMBC ス ペクトルにおける遠隔相関により確認した。 今まで L-arabinose の 2 位水酸基に D-glucose などの ${ }^{4} \mathrm{C}_{1}$ 型 配座の糖が結合した場合， L-arabinose が $^{1} \mathrm{C}_{4}$ 型配 

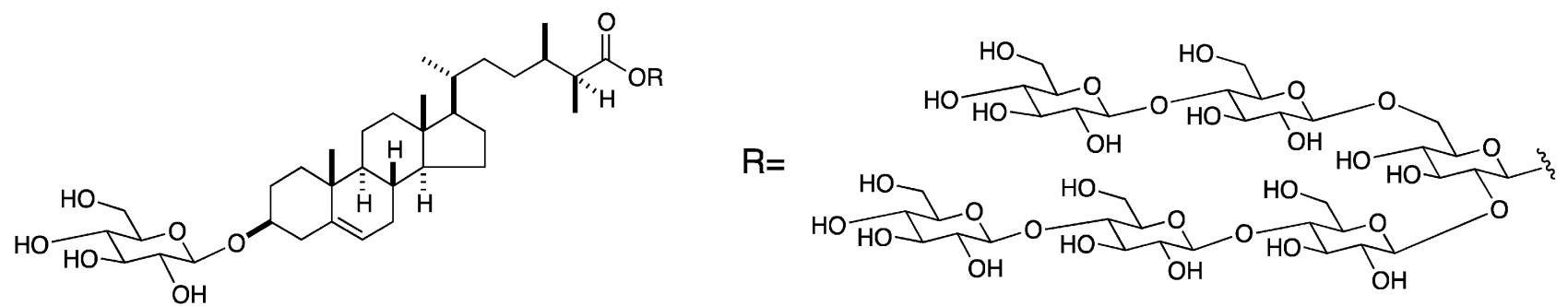

Fig. 8. Structure of TC-18

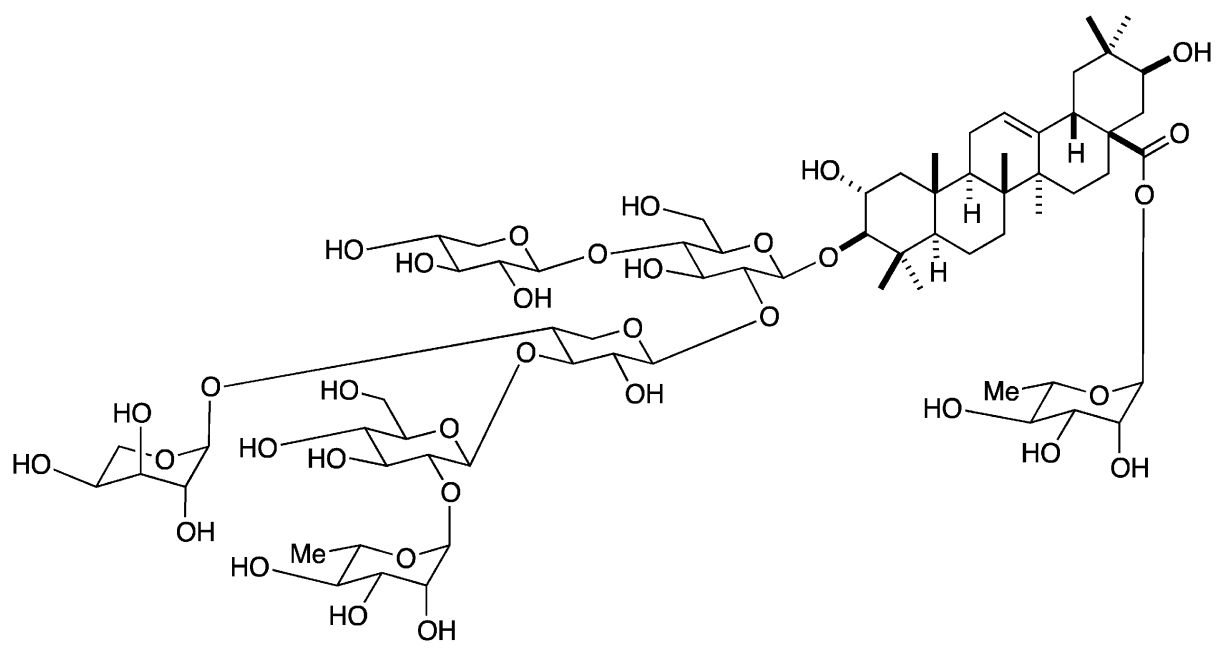

Fig. 9. Structure of SF-3

座をとることが報告されているが，SF-3 のように 末端 arabinose が $^{1} \mathrm{C}_{4}$ 型配座をとる例はこれが初め てである (Fig. 9). ${ }^{25,26)}$

これらの配糖体成分には現在のところ，顕著な生 物活性は見つかっていないが，天然配糖体の化学構 造という観点からは極めて興味深い。

\section{6. おわりに}

高等植物を含めた天然資源の成分探索研究の結 果，現在でもなお，構造の多様性に富んだ新規化合 物や，強い生物活性を有する化合物が数多く見い出 されている，今後も様々な植物を対象として，構造 的に興味深く, 強い腫瘍細胞毒性を示す化合物を探 索し, 構造活性相関と作用メカニズムの解明を継続 して行っていく予定である.

謝辞本研究は, 東京薬科大学薬学部漢方資源 応用学教室において行われたものであり, 三巻祥浩 教授を始めとする教室スタッフ, 大学院生，学生諸 氏，並び一連のご指導ご協力を頂きました諸先生方 に厚く御礼申し上げます。 利益相反＼cjkstart開示すべき利益相反はない.

\section{REFERENCES}

1) Newman D. J., Cragg G. M., J. Nat. Prod., 75, 311-335 (2012).

2) Yamori T., Matsunaga A., Sato S., Yamazaki K., Komi A., Ishizu K., Mita I., Edatsugi H., Matsuba Y., Takezawa K., Nakanishi O., Kohno H., Nakajima Y., Komatsu H., Andoh T., Tsuruo T., Cancer Res., 59, 4042-4049 (1999).

3) Yokosuka A., Haraguchi M., Usui T., Kazami S., Osada H., Yamori T., Mimaki Y., Bioorg. Med. Chem. Lett., 17, 3091-3094 (2007).

4) Hayakawa I., Ikedo A, Kigoshi H., Chem. Lett., 36, 1382-1383 (2007).

5) Ikedo A., Hayakawa I., Usui T., Kazami S., Osada H., Kigoshi H., Bioorg. Med. Chem. Lett., 20, 5402-5404 (2010).

6) Hayakawa I., Ikedo A., Chinen T., Usui T., Kigoshi H., Bioorg. Med. Chem. Lett., 20, 5745-5756 (2012). 
7) Chinen T., Kazami S., Nagumo Y., Hayakawa I., Ikedo A., Takagi M., Yokosuka A., Imamoto N., Mimaki Y., Kigoshi H., Osada H., Usui T., ACS Chem. Biol., 8, 884-889 (2013).

8) Yokosuka A., Mimaki Y., Chem. Pharm. Bull., 55, 145-149 (2007).

9) Yokosuka A., Mimaki Y., Phytochemistry, 69, 2724-2730 (2008) .

10) Yokosuka A., Mimaki Y., Phytochemistry, 70, 807-815 (2009).

11) Yokosuka A., Sano T., Hashimoto K., Sakagami H., Mimaki Y., Chem. Pharm. Bull., 57, 1161-1166 (2009) .

12) Yokosuka A., Suzuki T., Mimaki Y., Chem. Pharm. Bull., 60, 275-279 (2012).

13) Yokosuka A., Takagi K., Mimaki Y., J. Nat. Med., 67, 590-598 (2013).

14) Yokosuka A., Jitsuno M., Yui S., Yamazaki M., Mimaki Y., J. Nat. Prod., 72, 1399-1404 (2009) .

15) Yokosuka A., Suzuki T., Tatsuno S., Mimaki Y., Phytochemistry, 101, 109-115 (2014).

16) Jitsuno M., Yokosuka A., Hashimoto K., Amano O., Sakagami H., Mimaki Y., Nat.
Prod. Commun., 6, 187-192 (2011) .

17) Yokosuka A., Mimaki Y., Chem. Pharm. Bull., 55, 273-279 (2007).

18) Yokosuka A., Mimaki Y., Sakuma C., Sashida Y., Steroids, 70, 257-265 (2005).

19) Yokosuka A., Mimaki Y., Sashida Y., Chem. Pharm. Bull., 52, 1396-1398 (2004).

20) Yokosuka A., Mimaki Y., Sashida Y., J. Nat. Prod., 66, 876-878 (2003).

21) Yokosuka A., Mimaki Y., Sakagami H., Sashida Y., J. Nat. Prod., 65, 283-289 (2002).

22) Yokosuka A., Mimaki Y., Sashida Y., J. Nat. Prod., 65, 1293-1298 (2002).

23) Yokosuka A., Mimaki Y., Sashida Y., Phytochemistry, 61, 73-78 (2002).

24) Yokosuka A., Mimaki Y., Sashida Y., Natural Medicines, 56, 208-211 (2002).

25) Yokosuka A., Kawakami S., Haraguchi M., Mimaki Y., Tetrahedron, 64, 1474-1481 (2008).

26) Yokosuka A., Kawakami S., Haraguchi M., Mimaki Y., Phytochem. Lett., 4, 259-266 (2011). 